\title{
Overexpression of modified human TR $\beta 1$ suppresses the growth of hepatocarcinoma SK-hep1 cells in vitro and in xenograft models
}

\author{
Xiaoxiang Peng ${ }^{1,2} \cdot$ Yuntao Zhou $^{3} \cdot$ Yanli Sun $^{1,2} \cdot$ Wei Song $^{1,2} \cdot$ Xiangying Meng $^{1,2} \cdot$ Chunling Zhao ${ }^{4} \cdot$ Ronglan Zhao $^{1,2}$
}

Received: 29 December 2017 / Accepted: 16 April 2018 / Published online: 20 April 2018

(c) The Author(s) 2018

\begin{abstract}
Association studies suggest that TR $\beta 1$ functions as a tumor suppressor. Thyroid hormone receptors (TRs) mediate transcriptional responses through a highly conserved DNA-binding domain (DBD). We previously constructed an artificially modified human TR $\beta 1$ (m-TR $\beta 1)$ via the introduction of a 108-bp exon sequence into the corresponding position of the wild-type human TR $\beta 1$ (TR $\beta 1$ ) DBD. Studies confirmed that $\mathrm{m}$-TR $\beta 1$ was functional and could inhibit the proliferation of breast cancer MDA-MB-468 cells in vitro. To understand the role of m-TR $\beta 1$ in liver tumor development, we adopted a gain-of-function approach by stably expressing TR $\beta$ (m-TR $\beta 1$ and TR $\beta 1$ ) genes in a human hepatocarcinoma cell line, SK-hep1 (without endogenous TR $\beta$ ), and then evaluated the effects of the expressed TR $\beta$ on cancer cell proliferation, migration, and tumor growth in cell-based studies and xenograft models. In the presence of 3,5,3-L-triiodothyronine (T3), the expression of TR $\beta$ in SK-hep1 cells inhibited cancer cell proliferation and impeded tumor cell migration through the up-regulation of 4-1BB, Caspase-3, and Bak gene expression; down-regulation of Bcl-2 gene expression; and activation of the Caspase-3 protein. $\mathrm{TR} \beta$ expression in SK-hep1 led to less tumor growth in xenograft models. Additionally, the anti-tumor effect of m-TR $\beta 1$ was stronger than that of TR $\beta 1$. These data indicate that $\mathrm{m}$-TR $\beta 1$ can act as a tumor suppressor in hepatocarcinoma and its role was significantly better than that of TR $\beta 1$.
\end{abstract}

Keywords TR $\beta 1 \cdot$ Tumor suppressor $\cdot$ Hepatocarcinoma $\cdot$ SK-hep1 cells

\section{Introduction}

TRs are members of a superfamily that comprises the nuclear receptors and ligand-dependent transcription factors that mediate the biological actions of thyroid hormone (T3) in differentiation, growth, development, and the maintenance

Xiaoxiang Peng and Yuntao Zhou have contributed equally to this work.

Ronglan Zhao

zhaoronglan76@sina.com

1 Department of Laboratory Medicine, Weifang Medical University, Weifang 261053, Shandong, China

2 Key Discipline of Clinical Laboratory Medicine of Shandong Province, Affiliated Hospital of Weifang Medical University, Weifang 261053, Shandong, China

3 Central Hospital of Zibo, Zibo 255020, Shandong, China

4 Key Laboratory of Biological Medicine in Universities of Shandong Province, Weifang Medical University, Weifang 261053, Shandong, China of metabolic homeostasis [1, 2]. TRs are encoded by two human genes, namely, THRA and THRB; furthermore, four DNA- and T3-binding isoforms, namely, TR $\alpha 1$, TR $\beta 1$, TR $\beta 2$, and TR $\beta 3$ (only present in rat), are generated by alternative mRNA splicing and differential promoter usage [2]. These isoforms are functional receptors and share a common structure in several regions ranging from the $\mathrm{N}$-terminus to the $\mathrm{C}$-terminus: an $\mathrm{N}$-terminal activation domain $(\mathrm{A} / \mathrm{B})$, a conserved DNA-binding domain (DBD) (C), a hinge domain (D), and a ligand-binding domain (E/F). TRs regulate target gene transcription by interacting with specific DNA sequences, known as thyroid hormone response elements (TREs) [3]. Several recent studies have strongly suggested that TR $\beta$ plays an important role in cell proliferation and malignant transformation [4-7]. Low or even no expression of TRs and alterations in TR genes, especially TR $\beta 1$, have been identified in many types of cancer [8-12]. Studies have also demonstrated that mutations in TR $\beta 1$ are closely associated with many cancers [13-16]. Many studies have confirmed that TR $\beta 1$ plays as a tumor suppressor in human cancers [17-19]. 
We previously identified a novel rat TR $\beta$ (rTR $\beta$ ) isoform with an extra-large DBD, named TR beta delta $(\mathrm{TR} \beta \Delta$, GenBank number: DQ191165). $\operatorname{rTR} \beta \Delta$ is highly homologous to rat TR $\beta 1$ (rTR $\beta 1$ ) and contains an additional 108 nucleotides or 36 amino acids in the DBD, which alters this highly conserved domain [20]. Nevertheless, studies have demonstrated that $\operatorname{rTR} \beta \Delta$ is a functional TR, that $\operatorname{rTR} \beta \Delta$ has transcription factor characteristics, and that $\operatorname{rTR} \beta \Delta$ exhibits a greater tumor-suppressive ability in vitro than rTR $\beta 1$. Subsequently, we constructed an artificial $m-T R \beta 1$ by introducing this new 108-bp exon into the DBD of human TR $\beta 1$. $\mathrm{m}$-TR $\beta 1$ was functional in MDA-MB-468 cells and inhibited MDA-MB-468 cell proliferation by promoting apoptosis in the presence of T3. However, the roles of $m-T R \beta 1$ in other cancer cell lines in vitro and in tumorigenesis in vivo are currently unknown.

In the present study, we adopted a gain-of-function approach by expressing the human TR $\beta$ (m-TR $\beta 1$ and TR $\beta 1$ ) gene in human hepatocarcinoma cells, namely, SKhep1. We stably expressed the TR $\beta$ gene in SK-hep1 cells and evaluated the effects of TR $\beta$ expression on cell proliferation, apoptosis, migration, and tumor development in xenograft models. We found that TR $\beta$ gene expression in the presence of T3 promoted SK-hep1 apoptosis, inhibited SK-hep1 proliferation, and impeded migration. These inhibitory responses were mediated by the up-regulation of $4-1 B B$, Caspase-3, and Bak gene expression, down-regulation of $B c l-2$ gene expression, and activation of the Caspase- 3 protein due to the expression of TR $\beta$. Moreover, the expression of TR $\beta$ in SK-hep1 significantly reduced SK-hep1 tumor growth in xenograft models. Further analysis indicated that the effects of $\mathrm{m}$-TR $\beta 1$ were stronger than those of TR $\beta 1$. Thus, m-hTR $\beta 1$ could act as a tumor suppressor in hepatocarcinoma cells.

\section{Materials and methods}

\section{Animals and reagents}

A human hepatocarcinoma cell line (SK-hep1) was obtained from the Cell Bank of the Chinese Academy of Sciences (Shanghai, China). 293T cells and lentiviral vector GV358 were purchased from GeneChem (Shanghai, China). DMEM was purchased from Gibco (CA, USA). The Annexin V-FITC apoptosis detection kit, the NE-PER ${ }^{\mathrm{TM}}$ nuclear and cytoplasmic extraction reagents, and thyroid hormone receptor beta-1 antibody were purchased from (Thermo Fisher, MA, USA). Other reagents were obtained as follows: GAPDH antibody (Santa Cruz, CA, USA); the Bcl-2, 4-1BB, Bak, Histone H3, and active Caspase- 3 antibodies (Bioss, Beijing, China); the TRIzol total RNA extraction reagent, the InFusion $^{\mathrm{TM}}$ PCR cloning kit, and quantitative real-time PCR detection kit (Takara, Dalian, China); M-MLV reverse transcriptase (Invitrogen, CA, USA); KOD-Plus-Ver polymerase (TOYOBO, Tokyo, Japan); the Caspase-3 spectrophotometric assay kit (NANJING KEYGEN BIOTECH. CO., LTD, Nanjing, China); and MTT (3-(4,5-dimethylthiazol2-yl)-2,5-diphenyltetrazolium bromide) (Promega, Beijing, China). Four-week-old female BALB/c nude mice (15-18 g) were obtained from Shanghai Lingchang BioTech CO., Ltd (Shanghai, China). Protocols involving animals used in this study were approved by the Institutional Animal Care and Use Committee of Weifang Medical University.

\section{In vitro experiments}

\section{Construction of GV358-TR $\beta 1$ and GV358-m-TR $\beta 1$ vectors}

Using PCR, we obtained the total sequence of wild-type human $T R \beta 1$ (TR $\beta 1)$ and artificially modified the human TR $\beta 1$ (m-TR $\beta 1)$ cDNA from pcDNA3.1-wt-hTR $\beta 1$ and pcDNA3.1-m- $h T R \beta 1$ (previously constructed and stored by our team). The forward primer was 5'-GAGGATCCC CGGGTACCGGTCGCCACCATGACTCCCAAC AGT ATGACAG-3', and the reverse primer was 5'-TCCTTG TAGTCCATACCATCCTCGAACACTTCCAAGAAC- ${ }^{\prime}$. The PCR product was directionally cloned into the lentiviral vector GV358, which was linearized with Age I with the In-Fusion ${ }^{\mathrm{TM}}$ PCR cloning kit according to the manufacturer's protocol. The constructed expression vectors, namely, GV358-TR $\beta 1$ and GV358-m-TR $\beta 1$, were confirmed via sequence analysis.

\section{Viral packaging}

The GV358-TR $\beta 1$, GV358- $m-T R \beta 1$, or GV358 empty vector plasmid was co-transfected with the Helper 1.0 and Helper 2.0 packaging helper plasmids (GeneChem, Shanghai, China) into $293 \mathrm{~T}$ cells with a mass ratio of $4: 3: 2$. The culture supernatants were harvested at $48 \mathrm{~h}$ post-transfection to purify the lentiviruses expressing TR $\beta 1, \mathrm{~m}-\mathrm{TR} \beta 1$, or the control. The lentiviruses were purified via ultracentrifugation (Beckman, CA, USA) at 25,000 rpm for $2 \mathrm{~h}$ at $4{ }^{\circ} \mathrm{C}$, and the viral titers were measured with endpoint dilution by ELISA (the HIV-1 p24 Antigen ELISA 2.0 assay kit according to the manufacturer's instructions). SK-hep 1 cells were infected with concentrated viruses (GV358-TR $\beta 1$, GV358-m-TR $\beta 1$, or GV358 empty vector) at a multiplicity of infection of 10 , and the infection solution was discarded $12 \mathrm{~h}$ after infection. Because the lentivirus vector contained GFP, the infection efficiency was determined by observing GFP-positive cells under a fluorescence microscope $72 \mathrm{~h}$ after infection. At $72 \mathrm{~h}$ post-infection, the SK-hep1 cells that stably expressed TR $\beta 1$ (SK-hep1-TR $\beta 1$ ) and m-TR $\beta 1$ (SK-hep1-m-TR $\beta 1$ ) 
were used for subsequent experiments. SK-hep1 cells were infected with the empty vector GV358 and served as control cells (SK-hep1-Neo). A portion of these cells was collected for Western blot. The total protein was resolved by $10 \%$ SDS-PAGE and transferred from the gel to PVDF membranes. The PVDF membranes were blocked for nonspecific reactivity with TBS-T containing 5\% non-fat milk for $2 \mathrm{~h}$ at room temperature (RT) and then incubated with primary antibodies (TR $\beta 1$ or $\mathrm{H} 3,1: 1000$ dilution) at $4{ }^{\circ} \mathrm{C}$ overnight. TR $\beta 1$ recognizes an epitope in the A/B domain of TR $\beta 1$, namely, amino acid residues $1-101$, which comprises a common sequence between TR $\beta 1$ and m-TR $\beta 1$. After thoroughly washes in TBS-T, the membranes were incubated with the secondary HRP antibodies (antimouse, 1:5000 dilution) for $1.5 \mathrm{~h}$ at RT. After thorough washes with TBS-T, the membranes were visualized using enhanced chemiluminescence and Kodak films (Kodak, Rochester, USA).

\section{Cell proliferation and apoptosis assays}

MTT assays were employed to measure cell proliferation. SK-hep1-TR $\beta 1$ cells, SK-hep1-m-TR $\beta 1$ cells, and SKhep1-Neo cells were seeded at a density of $1 \times 10^{4} / \mathrm{mL}$ into 96-well plates, and then, $10 \mathrm{nM} \mathrm{T3}$ was added to the intervention groups. After $48 \mathrm{~h}$, a sterile-filtered MTT solution $(20 \mu \mathrm{L}, 5 \mathrm{mg} / \mathrm{mL})$ was added to each well, followed by incubation for $4 \mathrm{~h}$ at $37{ }^{\circ} \mathrm{C}$. Then, the formazan crystals were solubilized in dimethyl sulfoxide. The absorbance at $570 \mathrm{~nm}$ was recorded using a microplate reader (BIO-RAD, CA, USA), and the background absorbance at $630 \mathrm{~nm}$ was subtracted.

SK-hep1-TR $\beta 1$ cells, SK-hep1- $m$-TR $\beta 1$ cells, and SKhep1-Neo cells were seeded in 12-well plates, and then, $10 \mathrm{nM}$ T3 was added to the intervention groups. After $48 \mathrm{~h}$ of culture, cells were harvested and stained with FITCconjugated Annexin $\mathrm{V}$ and propidium iodide for $10 \mathrm{~min}$ at RT and detected by flow cytometry (BD, New Jersey, USA).

\section{Wound healing assay}

SK-hep1-TR $\beta 1$ cells, SK-hep1-m-TR $\beta 1$ cells, and SK-hep1Neo cells were seeded at $1 \times 10^{6}$ cells per well in six-well plates. A pipette tip was used to introduce wounds to confluent cells, plates were washed with PBS, and culture medium (without serum) was added. Cells were further cultured in the medium with or without $\mathrm{T} 3(10 \mathrm{nM})$. At regular intervals, a camera system with an inverted microscope was used to visualized cell migration at $\times 100$ magnification. The migration rate was quantified by measuring the distances between the edges of wound, and the percentage of migration was determined as the ratio of the migrated distance to the initial distance of the wound [21].

\section{Real-time fluorescent quantitative PCR (RT-qPCR) and Western blot}

SK-hep1-TR $\beta 1$ cells, SK-hep1- $m$-TR $\beta 1$ cells, and SK-hep1Neo cells were seeded in 6-well plates, and then, $10 \mathrm{nM}$ T3 was added to the intervention groups. After $48 \mathrm{~h}$, the cells were harvested for total RNA and protein extractions. Total RNA was extracted using the TRIzol reagent. mRNA $(2 \mu \mathrm{g})$ was reverse transcribed into total cDNA in a $20 \mu \mathrm{L}$ reaction mixture, and the mRNA levels of $4-1 B B, B c l-2, B a k$, and Caspase-3 were analyzed by RT-qPCR, using the Gapdh gene as a reference gene. PCR reactions were performed in iQ5TM (BIO-RAD, USA) and detected with SYBR Green. The primers for each gene are shown in Table 1. The PCR cycling conditions were as follows: $95^{\circ} \mathrm{C}$ for $30 \mathrm{~s}$, followed by 35 cycles of $95^{\circ} \mathrm{C}$ for $5 \mathrm{~s}, 56^{\circ} \mathrm{C}$ for $20 \mathrm{~s}$, and $72{ }^{\circ} \mathrm{C}$ for $20 \mathrm{~s}$. The $\mathrm{CT}$ values of all genes from the different samples were gathered, and the raw data were calibrated to the data for Gapdh. The mRNA of each sample was normalized, and

Table 1 Primers for each gene

\begin{tabular}{lllll}
\hline Gene name & Gene symbol & Accession number & $\begin{array}{l}\text { Amplicon } \\
\text { length (bp) }\end{array}$ & Primer sequences \\
\hline Glyceraldehyde-3-phosphate dehydrogenase & GAPDH & NM_001256799.2 & 162 & $\begin{array}{l}\text { Forward: gCATCCTgggCTACACTgAg } \\
\text { Reverse: CCACCACCCTgTTgCTgTAg }\end{array}$ \\
B-cell lymphoma-2 & Bcl-2 & NM_000633.2 & 178 & $\begin{array}{l}\text { Forward: TgTgTgTggAgAgCgTCAAC } \\
\text { Reverse: gACAgCCAggAgAATCAAAC } \\
\text { TNF receptor superfamily member 9 }\end{array}$ \\
Caspase 3 & 4-1BB & NM_001561.5 & 164 & $\begin{array}{l}\text { Forward: gTTgCTCTTCCTgCTgTTC } \\
\text { Reverse: ATCCTCCTTCTTCTTCTTCTg } \\
\text { BCL2 antagonist/killer 1 }\end{array}$ \\
& Caspase-3 & NM_004346.3 & 162 & $\begin{array}{l}\text { Forward: ggAAgCgAATCAATggACTC } \\
\text { Reverse: TTCCCTgAggTTTCTgC } \\
\text { Forward: TACCgCCATCAgCAggAAC } \\
\text { Reverse: TCTgAgTCATAgCgTCggTTg }\end{array}$ \\
\hline
\end{tabular}


the relative expression level of each gene was represented as $2^{-\Delta \Delta C_{\mathrm{T}}}$.

Western blot analysis was carried out as described above. The primary antibodies used were against TR $\beta 1$ (1:1000), GAPDH (1:1000), Bcl-2 (1:100), active Caspase-3 (1:200), and Bak (1:100).

\section{Caspase-3 activity assay}

SK-hep1-TR 1 cells, SK-hep1-m-TR $\beta 1$ cells, and SK-hep1$N e o$ cells were seeded in 6-well plates, and then, $10 \mathrm{nM}$ T3 was added to the intervention groups. After $48 \mathrm{~h}$, the cells were lysed in RIPA buffer, and the total protein concentration of each lysate was determined using the BCA protein assay kit from PIERCE (PIERCE, USA). Caspase-3 activity was measured using the Caspase-3 spectrophotometric assay kit according to manufacturer's instructions.

\section{In vivo experiments}

\section{$\mathrm{BALB} / \mathrm{C}$ nude mouse transplantation}

Four-week-old female BALB/c nude mice were purchased from Shanghai Lingchang BioTech CO., Ltd [Certificate of Quality No: SCXK (Shanghai) 2013-0018]. Mice were housed four per cage and provided with free access to water, food, and bedding at all times. The mice were randomly separated into three groups comprising ten mice: (1) the SK-hep1-TR $\beta 1$ cell group, (2) the SK-hep1-m-TR $\beta 1$ cell group, and (3) the SK-hep1-Neo cell group. SK-hep1-TR $\beta 1$ cells, SK-hep1-m-TR $\beta 1$ cells, and SK-hep1-Neo cells were digested and respectively implanted into the skin of the right forelimb armpit of each nude mouse in a total volume of $200 \mu \mathrm{L}\left(4 \times 10^{6}\right)$ cells resuspended in D-Hanks without fetal bovine serum (FBS), under aseptic conditions. Two weeks after cell inoculation, primary tumor outgrowth was monitored three times per week by measuring the tumor width $(W)$ and length $(L)$ with a digital caliper. The tumor volume was calculated as follows: $\pi / 6 \times L \times W \times W$. Tumor growth was evaluated up to day 56 after cell inoculation. Eight weeks after inoculation, the tumor-bearing mice were anesthetized with Peltobalrbitalum Natricum, imaged using the Small Animal Live Imaging System (Berthold Technologies, Germany), and sacrificed by cervical dislocation. The tumors were removed, weighed, and used to examine the parameters described below.

\section{Western blot and immunohistochemical analysis}

Two samples were randomly selected from each group to extract total protein for the detection of TR $\beta 1$ and $\mathrm{m}-\mathrm{TR} \beta 1$ protein. The Western blot analysis was carried out as described above. The tumor tissue was fixed in $10 \%$ buffered formalin for $24 \mathrm{~h}$ and then embedded in paraffin. Four-micrometer sagittal sections were made and processed for immunohistochemistry according to a standard protocol. Primary antibodies used were against active Caspase-3 (dilution 1:200), 4-1BB (1:50 dilution), Bcl-2 (1:200 dilution), and Bak (1:200 dilution). Staining was developed with 3,3-diaminobenzidine (DAB). Cells that were positive for active Caspase-3, 4-1BB, Bcl-2, or Bak were counted for quantitative analysis.

\section{Statistical analysis}

All measurement data are expressed as the mean \pm SD and were analyzed with SPSS 17.0. The single-factor analysis of variance was used for the multigroup comparisons. Each result was compared using the Student-Newman-Keuls test. A value of $p<0.05$ was considered significant.

\section{Results}

\section{Generation of wt-TRß1 and $m$-TR $\beta 1$ lentiviral expressing vectors}

A full-length coding sequence of $T R \beta 1(1386 \mathrm{bp})$ or $m-T R \beta 1(1494 \mathrm{bp})$ was directionally cloned into the GV358 lentiviral vector to obtain the GV358-TR $\beta 1$ expression plasmid. This sequence was completely consistent with the sequence published in GenBank and with the GV358$m$-TR $\beta 1$ expression plasmid. The sizes of the TR $\beta 1$ and $\mathrm{m}$-TR $\beta 1$ proteins were approximately 52 and $57 \mathrm{kD}$, respectively, as predicted from the aa sequence, and the proteins were expressed in SK-hep1 cells (without endogenous TR $\beta 1$ and $\mathrm{m}$-hTR $\beta 1$ ) (Fig. 1a). GFP was used as a reporter gene. GV358 (empty vector, $T R \beta 1$ or $m$-TR $\beta 1$ ) was successfully transduced into SK-hep1 cells since more than $80 \%$ of the cells in each group were GFP-positive by fluorescence microscopy at $72 \mathrm{~h}$ post-infection (Fig. 1b).

\section{m-TR $\beta 1$ inhibits the growth and migration of SK-hep1 cells}

To elucidate the functional consequences of the reexpression of m-TR $\beta 1$ in SK-hep1 cells, we generated SK-hep1 cells that stably expressed TR $\beta$ (TR $\beta 1, \mathrm{~m}-\mathrm{TR} \beta 1)$ or control SK-hep1 cells that stably expressed the empty vector GV358 (Neo). The protein abundance of TR $\beta$ in the SK-hep1-TR $\beta 1$ cells and SK-hep1- $m-T R \beta 1$ cells was confirmed by Western blot analysis (Fig. 2a), whereas no TR $\beta$ was detected in the control SK-hep1-Neo cells (Fig. 2a). When the cells were cultured in medium containing $10 \mathrm{nM}$ T3 without FBS, cancer cell proliferation was clearly lower for SK-hep1-m-TR $\beta 1$ cells than for 
$\mathbf{a}$

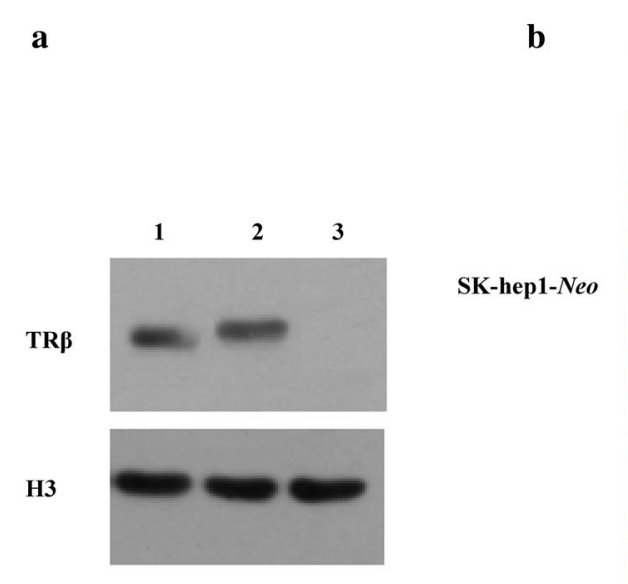

SK-hep1-TRß1

SK-hep1-m-TRß1

Fig. 1 Establishment of human hepatocarcinoma SK-hep1 cell lines stably expressing $\operatorname{TR} \beta 1$ and $\mathrm{m}-\mathrm{TR} \beta 1$. a $\operatorname{TR} \beta 1$ and $\mathrm{m}-\mathrm{TR} \beta 1$ were expressed in SK-hep1-TR $\beta$ cells (lanes 1 and 2) but not in control SK-hep1-Neo cells (lane 3). Western blot analysis was carried out as
SK-hep1 cells
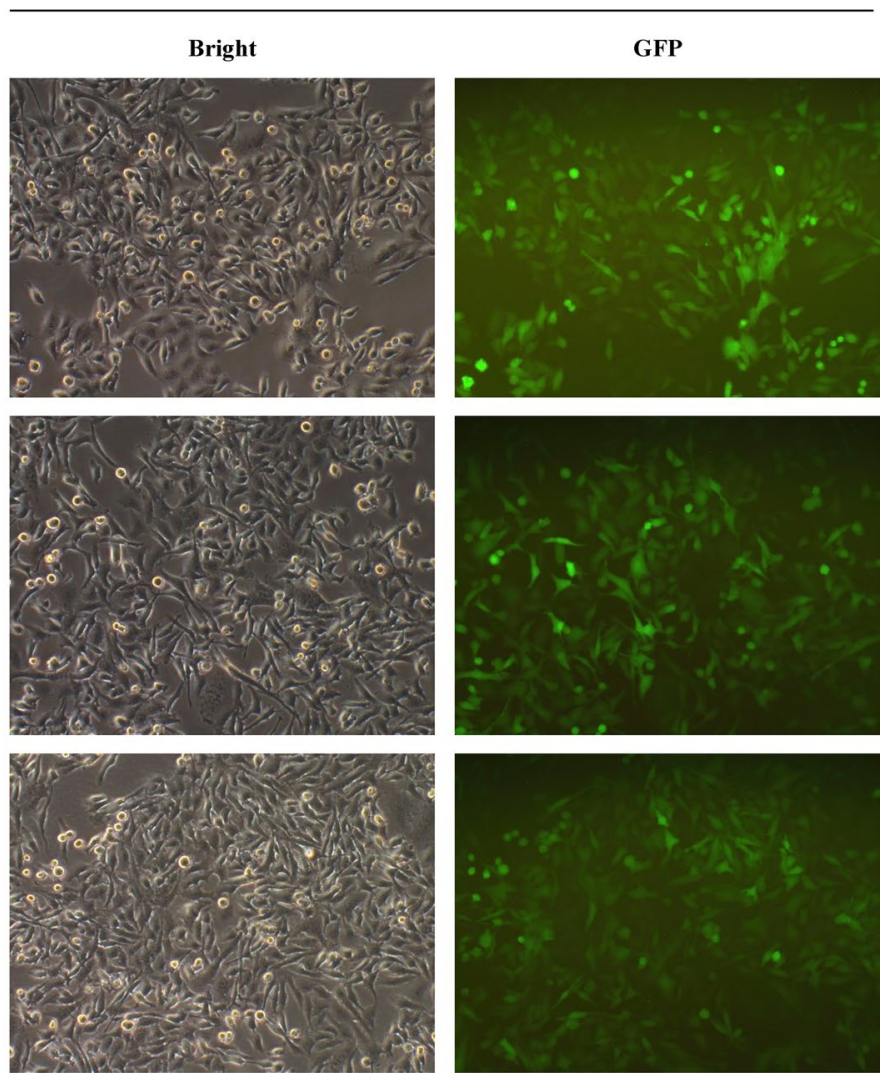

described in Materials and methods. b Representative micrographs of SK-hep1 cells under a $\times 100$ magnification microscope and under an inverted fluorescence microscope at $72 \mathrm{~h}$ following lentiviral infection (GV358-TR $\beta 1$, GV358-m-TR $\beta 1$, or GV358 empty vector)

SK-hep1-TR $\beta 1$ cells and SK-hep1-Neo cells $(p<0.05)$ (Fig. 2b). Significant differences were also observed between SK-hep1-TR $\beta 1$ cells and SK-hep1-Neo cells $(p<0.05)$ (Fig. 2b), whereas no T3 effect was observed on the proliferation of the SK-hep1-Neo cells that did not express TR $\beta$.

As shown in Fig. 2c, d, T3 had no apparent effect on the cell migration of SK-hep1-Neo cells. Interestingly, in the absence of T3, the migration rates of the SK-hep1$m-T R \beta 1$ and SK-hep1-TR $\beta 1$ cells were similar to that of the SK-hep1-Neo cells. However, in the presence of T3, the migration rates of the SK-hep1-m-TR $\beta 1$ cells and SK-hep1-TR $\beta 1$ cells were significantly slower than those of the SK-hep1-TR $\beta 1$ cells and SK-hep1-m-TR $\beta 1$ cells without T3. In the presence of $10 \mathrm{nM} \mathrm{T3}$, the inhibition of cell migration by m-TR $\beta 1$ was stronger than that by TR $\beta 1$ (Fig. 2c-d). Quantitative analysis showed that migration was significantly inhibited in both groups $(p<0.05)$. Data are presented as the mean $\pm \mathrm{SD}$, and the $p$ values are shown.

\section{m-hTRß1 promotes the apoptosis of SK-hep1 cells}

To understand how m-hTR $\beta 1$ expression inhibited SK-hep1 cell growth and migration in vitro, the effects of m-TR $\beta 1$ on SK-hep1 cell apoptosis were measured. SK-hep1-mTR $\beta 1$ cells, SK-hep1-TR $\beta 1$ cells, and SK-hep1-Neo cells were cultured with or without T3. Flow cytometric analysis showed that cancer cell apoptosis was clearly higher among the SK-hep1- $m$-TR $\beta 1$ cells than among the SK-hep1-TR 1 cells and SK-hep1-Neo cells $(p<0.05)$ (Fig. 3a). Significant differences were also observed between the SK-hep1TR $\beta 1$ cells and SK-hep1-Neo cells $(p<0.05)$; however, no T3 effect on the apoptosis of the Neo cells was observed (Fig. 3a). These flow cytometric analysis results prompted us to evaluate how the expression of m-TR $\beta 1$ promoted the apoptosis of SK-hep1. Therefore, the levels of apoptosisrelated genes were estimated by RT-qPCR. The RT-qPCR results showed that compared with the control Neo cells, in the presence of T3, m-hTR $\beta 1$ and TR $\beta 1$ caused a drastic increase in the 4-1BB, Bak, and Caspase-3 mRNA levels 

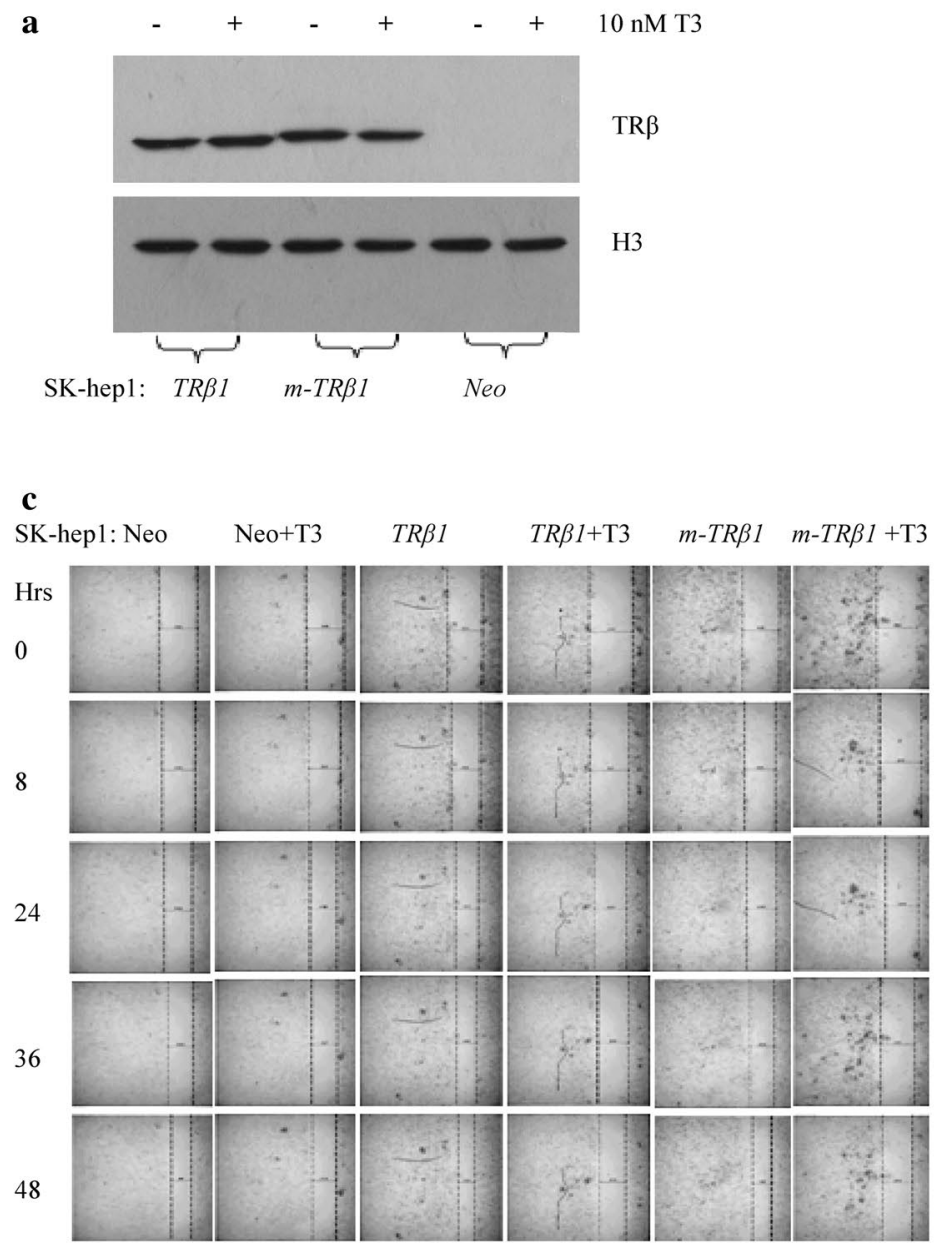

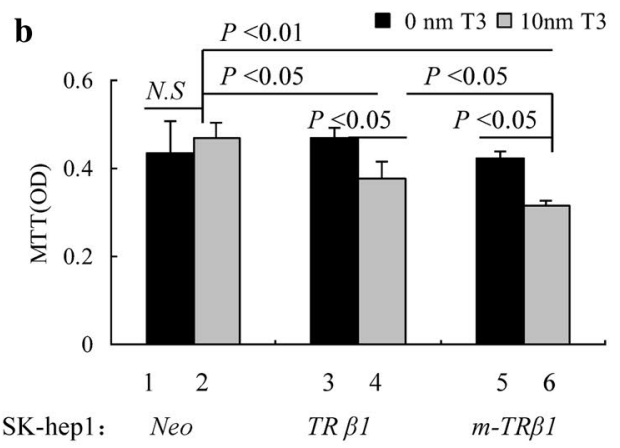

d

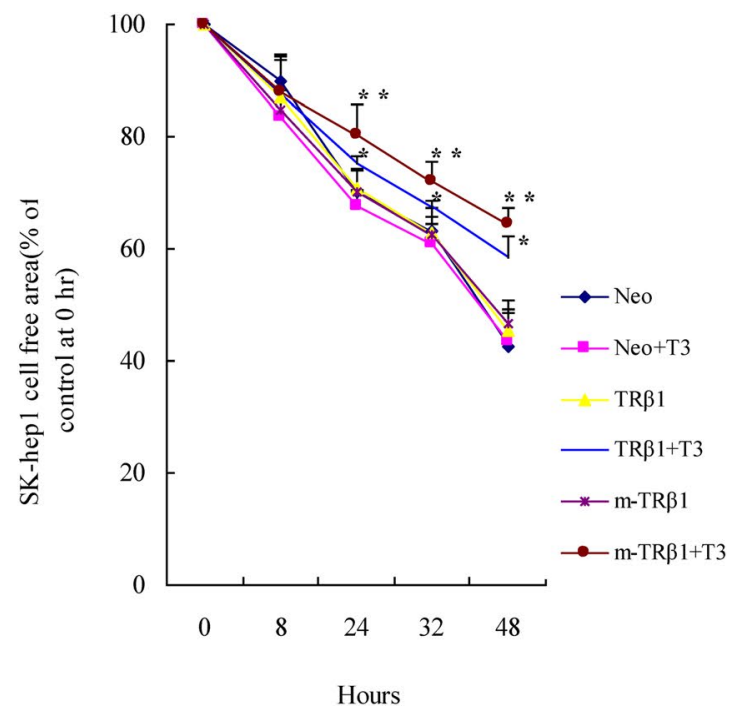

Fig. 2 Stable expression of TR $\beta$ in SK-hep1 cells reduces cell growth and migration. a Western blot analysis of the expression of TR $\beta 1$ and m-TR $\beta 1$ in SK-hep1-TR $\beta 1$ cells, SK-hep1-m-TR $\beta 1$ cells, and SKhep1-Neo cells. Western blot analysis was carried out as described in Materials and methods. b Cell growth was analyzed with MTT assays as described in Materials and Methods. Data are presented as the mean $\pm \mathrm{SD}(n=3)$, and the $p$ values are shown. $\mathbf{c}$ Representative cell pictures of wound healing in SK-hep1-TR $\beta 1$ cells, SK-hep1-m-TR $\beta 1$ cells, and in control SK-hep1-Neo cells at 0, 8, 24, 36, and $48 \mathrm{~h}$ (Hrs) in the presence or absence of $\mathrm{T} 3$ as marked. d Cell migration rates determined from results shown in c. $\mathrm{T} 3$ inhibited the migration rates

and a reduction in the $B c l-2$ mRNA level in SK-hep1 cells $(p<0.05)$; moreover, the effects of m-hTR $\beta 1$ were stronger than those of TR $\beta 1$ in the presence of $10 \mathrm{nM} \mathrm{T3}(p<0.05)$ (Fig. 3b). The Western blot results also showed that the expression levels of the 4-1BB, Bak, active Caspase-3, and Bcl-2 proteins (Fig. 3c) were consistent with the corresponding mRNA levels described above. Caspase-3 activity was also verified in cultured SK-hep1 cells using the Caspase-3 spectrophotometric assay kit. Compared with the control SK-hep1-Neo cells, in the presence of T3, the m-hTR $\beta 1$ and TR $\beta 1$ cells showed a gradual but significant up-regulation in Caspase 3 activity $(p<0.05)$ (Fig. $3 d)$. of the TR $\beta$-expressing SK-hep1 cells (TR $\beta 1$ and $m-T R \beta 1)$ relative to the rate of the control SK-hep1 cells (Neo). The effect of m-TR $\beta 1$ was stronger than that of TR $\beta 1$ on inhibiting cell migration in the presence of $10 \mathrm{nM}$ T3. Data are presented as the mean \pm SD. $* * p<0.01$, SK-hep1- $m$-TR $\beta 1$ cells in the presence of T3 versus SK-hep1- $m-T R \beta 1$ cells in the absence of T3, Neo control cells (presence or absence of T3) or SK-hep1-TR $\beta 1$ cells in the absence of T3. $* p<0.05$, SK-hep1$T R \beta 1$ cells in the presence of T3 versus SK-hep1-TR $\beta 1$ cells in the absence of T3, Neo control cells (presence or absence of T3) or SK-hep1- $m$-TR $\beta 1$ cells (presence or absence of T3)

\section{m-TR $\beta 1$ expression inhibits SK-hep1 cell tumor growth in mouse xenograft models}

To ascertain the role of m-TR $\beta 1$ in SK-hep1 cells, we inoculated SK-hep1-m-TR $\beta 1$ cells, SK-hep1-TR $\beta 1$ cells, and SKhep1-Neo cells into nude mice. A nude mouse xenograft model of human hepatocarcinoma was established, and the tumor formation rate was $100 \%$. As shown in Fig. $4 a$, b, the size of the tumor derived from the SK-hep1-m-TR 1 cells was clearly smaller than that of the tumor derived from the SK-hep1-TR $\beta 1$ cells, and the size of the tumor derived from the SK-hep1-TR $\beta 1$ cells was clearly smaller than that 

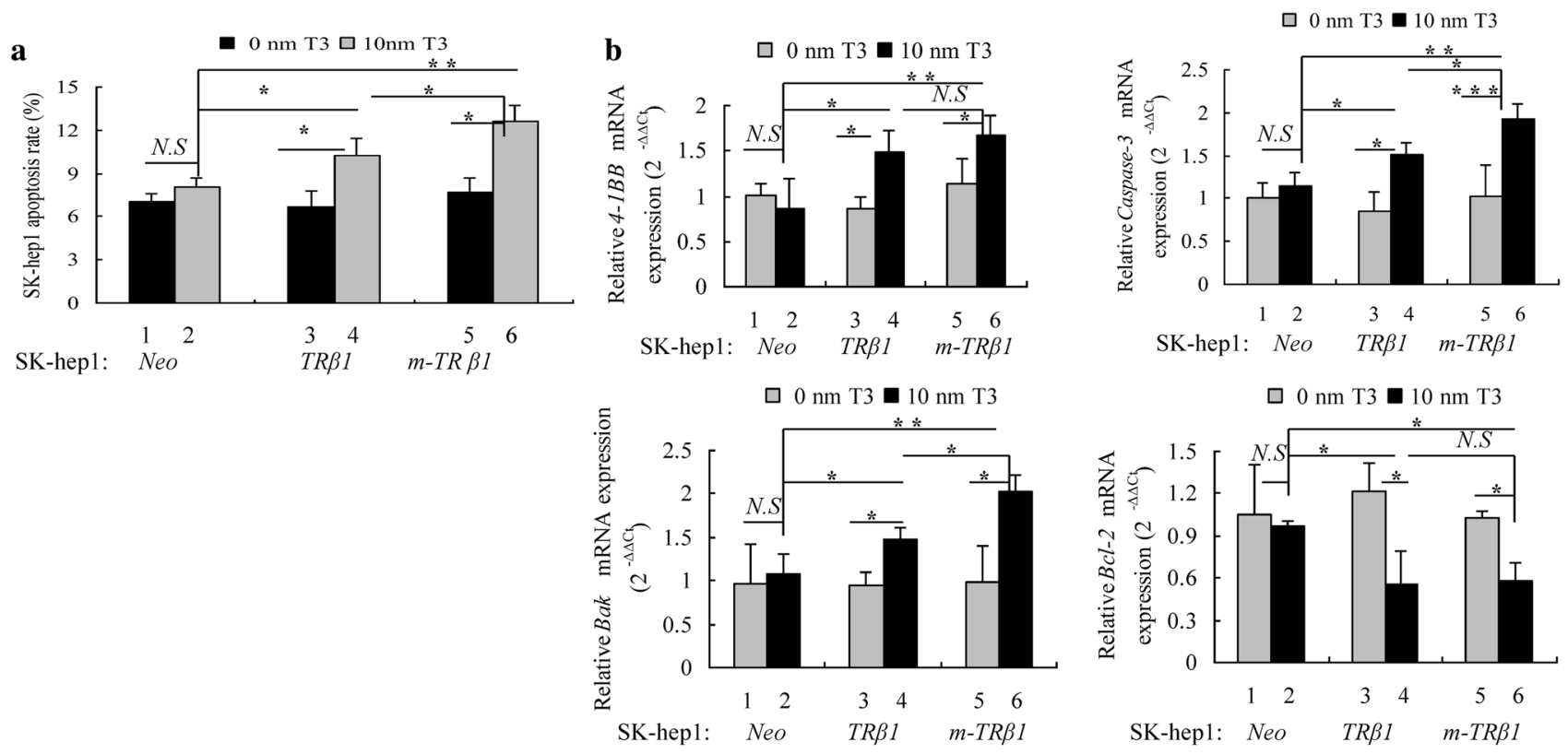

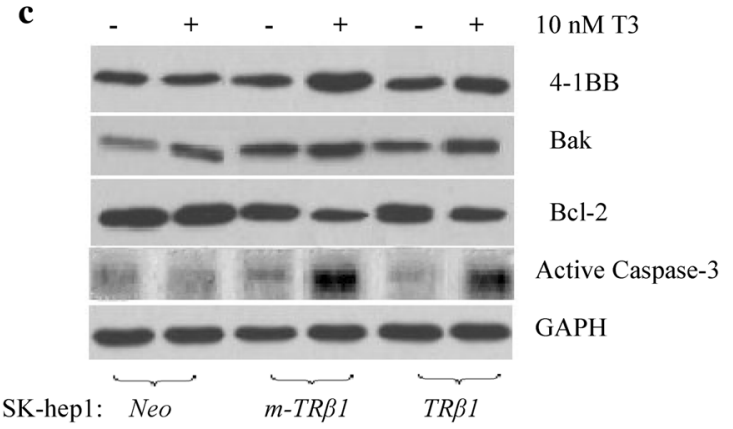

Fig. 3 Stable expression of TR $\beta$ in SK-hep1 cells promotes cell apoptosis. SK-hep1 cell apoptosis was detected with Annexin V-FITC. a The total number of apoptotic cells was determined by calculating the sum of the early apoptotic cells (Annexin $\mathrm{V}-\mathrm{FITC}^{+} / \mathrm{PI}^{-}$) and the late apoptotic cells (Annexin V-FITC ${ }^{+} / \mathrm{PI}^{+}$) detected by flow cytometry, and the data are presented as the mean $\pm \mathrm{SD}$. and the $p$ values are shown $(* p<0.05, * * p<0.01)$. b TR $\beta$ regulates the expression of genes involved in cell apoptosis. The relative expression levels of the transcripts for apoptosis-related genes were estimated by RT-qPCR in

of the tumor derived from the control Neo cells. As demonstrated by the quantitative comparison shown in Fig. $4 \mathrm{c}$, the tumor weights of the SK-hep1-m-TR $\beta 1$ and SK-hep1-TR $\beta 1$ tumors were significantly lower than those of the SK-hep1Neo tumors ( $p<0.01$ and $p<0.05$, respectively). As shown in Fig. 4d, the tumor growth rates of the SK-hep1-m-TR $\beta 1$ and SK-hep1-TR $\beta 1$ tumors were markedly slower than the growth rate of the control SK-hep1-Neo tumors. Among the three groups, the tumor growth rate of the SK-hep1-m-TR $\beta 1$ tumor group was lowest.

SK-hep1-m-TR $\beta 1$ cells, SK-hep1-TR $\beta 1$ cells, and SKhep 1-Neo cells inoculated into the nude mice expressed GFP, so GFP expression was observed with the in vivo

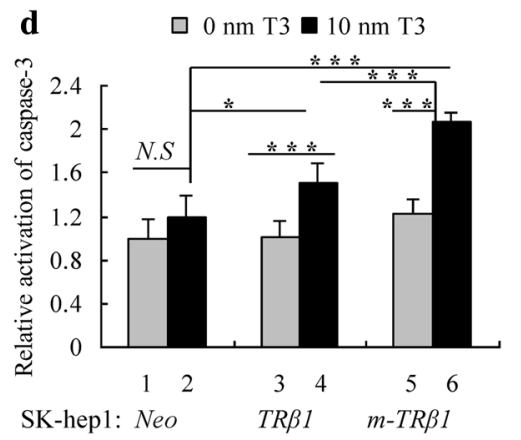

the SK-hep1-TR $\beta 1$, SK-hep1-m-TR $\beta 1$ and SK-hep1-Neo cells. Data were normalized to the amount of Gapdh mRNA and are represented as $2^{-\Delta \Delta C_{\mathrm{T}}}$. Data are presented as the mean $\pm \mathrm{SD}$, and the $p$ values are shown $(* p<0.05, * * p<0.01, * * * p<0.001)$. c Western blot analysis of apoptosis-related proteins in SK-hep1 cells. d Colorimetric assay of Caspase-3 activation. Caspase-3 activity was estimated by spectrophotometry. Data are presented as the mean $\pm \mathrm{SD}$, and the $p$ values are shown $(* p<0.05, * * * p<0.001)$

biofluorescence imaging system. The total amount of fluorescence in the area was used to indirectly reflect the number of fluorescently labeled cells or the size of the tumor volume. All nude mice were euthanized on the 56th day, and the mean fluorescence intensity of GFP was determined using the small animal live imaging system. The mean fluorescence intensity of the SK-hep1-mTR $\beta 1$ cells group was the lowest among the three groups $(p<0.05)$ (Fig. 5a, b). Consistent with the cell-based findings described above, the in vivo results indicated that $\mathrm{m}$-TR $\beta 1$ could act as a tumor suppressor in SK-hep1 cells and that the effects of $\mathrm{m}$-TR $\beta 1$ were significantly stronger than those of TR $\beta 1$. 


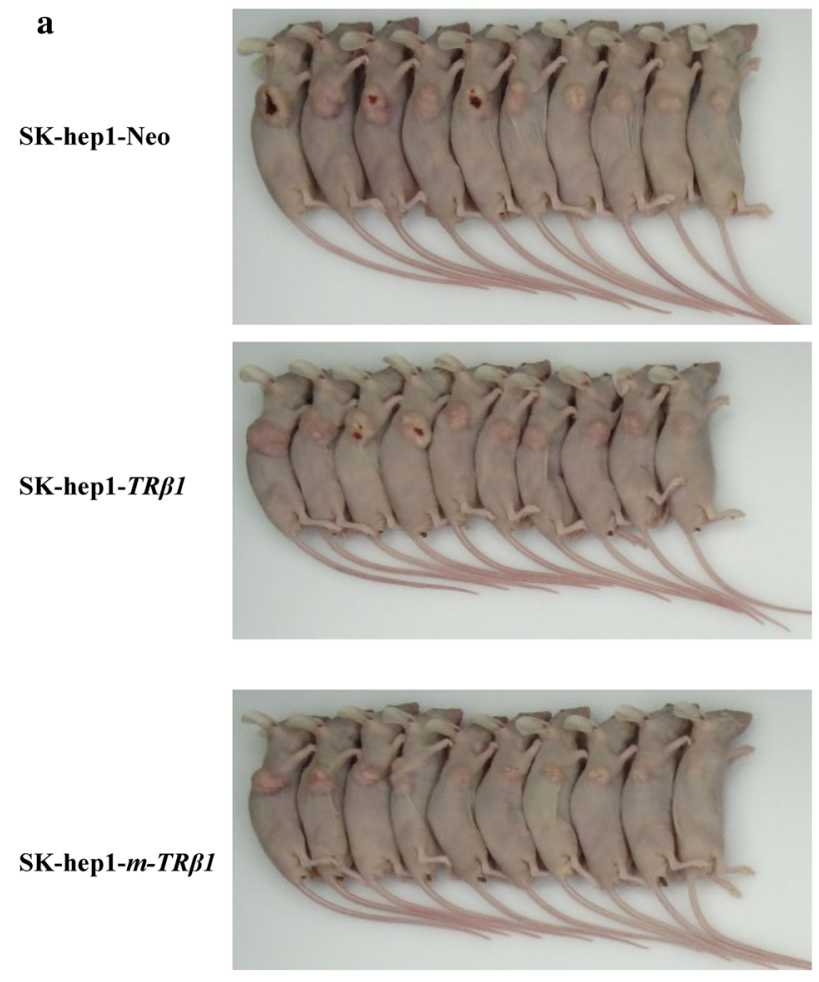

Fig. 4 Comparison of the growth rates of the tumors derived from the SK-hep1-TR $\beta 1$, SK-hep1-m-TR $\beta 1$, SK-hep1-Neo cells. a Representative pictures of the tumor-bearing mice. b Dissected tumors. c Tumors were dissected at the endpoint, and their weights were determined. Data are presented as the mean $\pm \mathrm{SD}$, and the $p$ values are

We assessed whether the slow growth of the SK-hep1$m-T R \beta 1$ tumors resulted from increased apoptosis. First, we confirmed that the TR $\beta 1$ and $\mathrm{m}-\mathrm{TR} \beta 1$ proteins were expressed in the SK-hep1-TR $\beta 1$ and SK-hep1-m-TR $\beta 1$ tumors but not in the SK-hep1-Neo control tumors (Fig. 6a). Second, apoptosis-related proteins were confirmed by immunohistochemical analysis of active Caspase-3, 4-1BB, $\mathrm{Bak}$, and Bcl-2 as markers in the tumors derived from the SK-hep1-TR $\beta 1$ cells, SK-hep1-m-TR $\beta 1$ cells, and SK-hep1Neo cells. Only a few cells within the SK-hep1-Neo tumors were stained with the anti-active Caspase-3, 4-1BB and Bak antibodies (Fig. 6b, panel a-c). However, more cells within the SK-hep1-TR $\beta 1$ tumors than within the SK-hep1Neo tumors were stained with the anti-active Caspase-3, 4-1BB, and Bak antibodies (Fig. 6b, panel e-g), and most cells within the SK-hep1-m-TR $\beta 1$ tumors were intensely stained with the anti-active Caspase-3, 4-1BB, and Bak antibodies (Fig. 6b, panel i-k). More cells in the SK-hep1Neo tumors (Fig. 6b, panel d) than in the SK-hep1-TR $\beta 1$ b

SK-hep1-Neo

SK-hep1-TRß1

SK-hep1-m-TRß1
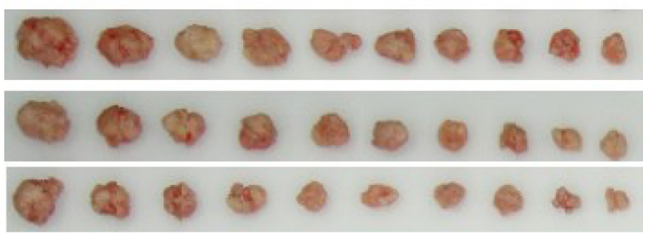

c

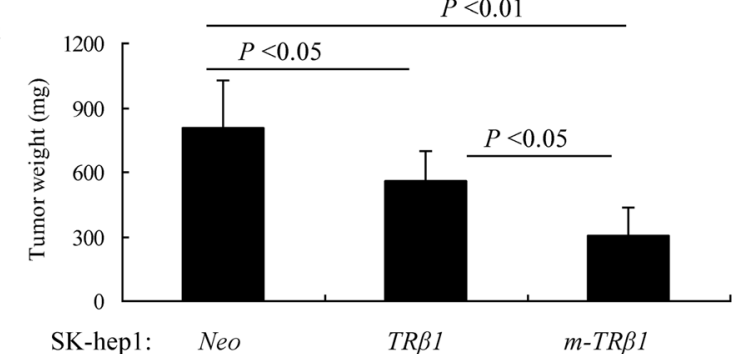

d

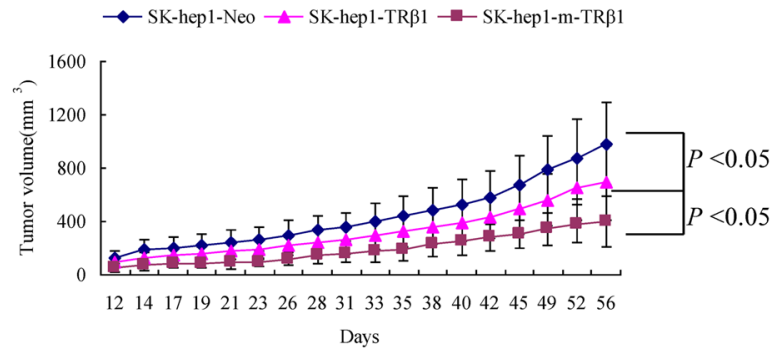

shown. d Beginning 2 weeks after cell inoculation, the tumor sizes were measured three times per week, and the rates of tumor growth were compared. The data are expressed as the mean $\pm \mathrm{SD}(n=10)$, and the $p$ values are shown

(Fig. 6b, panel h) and SK-hep1-m-TR $\beta 1$ tumors (Fig. 6b, panel l) were stained positively for Bcl-2. Among the three groups, the positive staining rate in the SK-hep1-m-TR $\beta 1$ tumors was lowest. The number of positively stained cells was counted, and the quantitative data are shown in Fig. 6c. Taken together, these data indicated that more tumor cells were underwent apoptosis in the SK-hep1-m-TR 1 1 tumors and that increased apoptotic activity in the m-TR $\beta 1$ tumors contributed to decreased tumor growth.

\section{Discussion}

Previous studies that have shown a close association between the reduced expression and high mutation rate of the TR $\beta 1$ gene and several human cancers support the hypothesis that TR $\beta 1$ can act as a tumor suppressor [8-13]. TR $\beta 1$ was previously shown to suppress tumor invasiveness and metastasis in human liver hepatocarcinoma cells (TR-deficient). When 


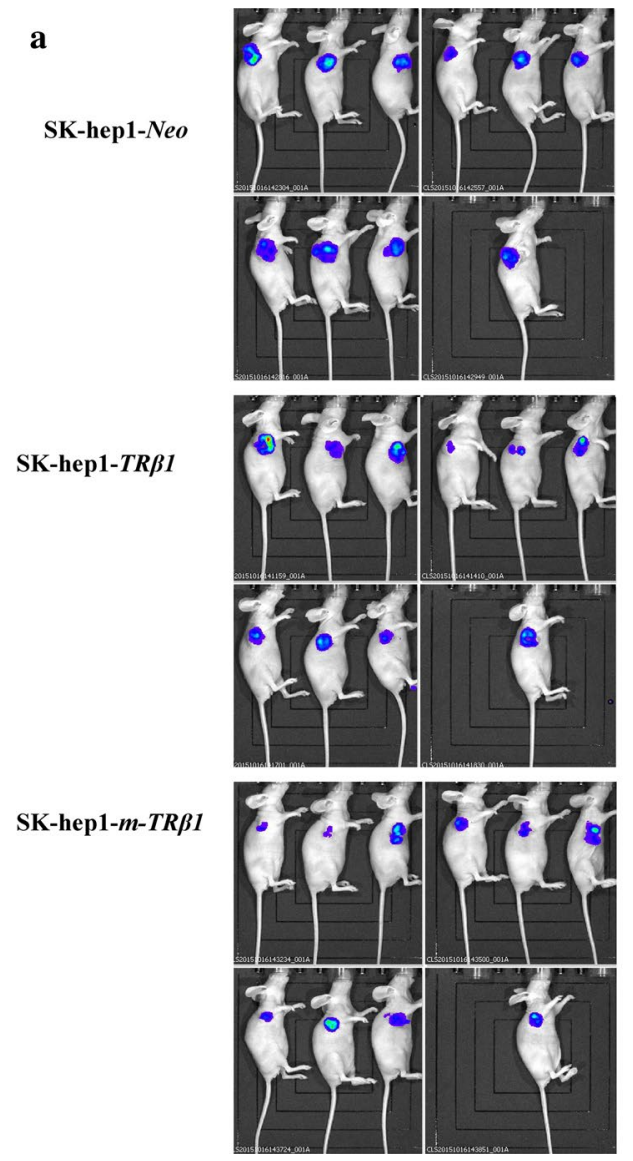

Fig. 5 Observation of in vivo biofluorescence imaging of the SKhep1-GFP tumors in the three groups BALB/c nude mice. a GFP expression in the inoculated SK-hep1 cells (stably expressing TR $\beta 1$, $\mathrm{m}$-TR $\beta 1$, or Neo) observed with an in vivo biofluorescence imaging system. The total amount of fluorescence in the area indirectly

TR $\beta 1$ was re-expressed in these cells, cell proliferation and migration were inhibited in vitro, and tumor growth was suppressed in xenograft models [21]. We previously constructed an artificially modified human TR $\beta 1$ (m-hTR $\beta 1)$ via the introduction of an extra 108-bp exon sequence into the corresponding position of the wild-type human TR $\beta 1$ (TR $\beta 1$ ) DBD. Studies have shown that $\mathrm{m}$-TR $\beta 1$ can function as a tumor suppressor in a human breast cancer cell line, MDA-MB-468, in vitro. At present, the detailed effects and mechanisms of m-TR $\beta 1$ in human hepatocarcinoma cells are unclear.

In the present study, we further showed that $\mathrm{m}-\mathrm{TR} \beta 1$ could also act as a tumor suppressor in another cancer cell line, namely, the SK-hep1 human hepatocarcinoma cell line. We adopted a gain-of-function approach by expressing TR $\beta$ (m-TR $\beta 1$ and TR $\beta 1$ ) in SK-hep1 cells. In vitro, the re-expression of TR $\beta$ in SK-hep1 cells increased apoptosis, decreased cell proliferation, and impeded cancer cell migration. Moreover, in addition to these cell-based results,

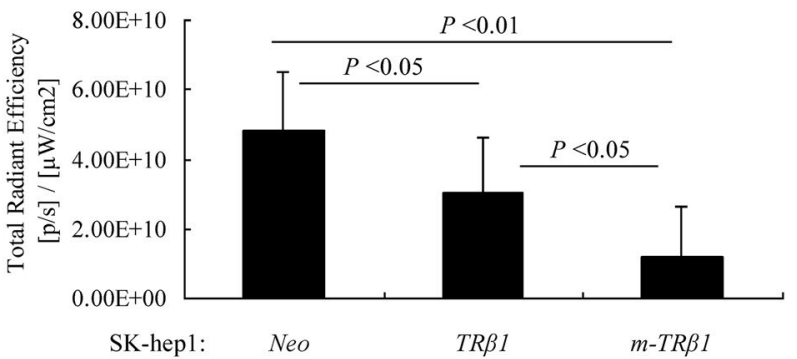

reflected the number of fluorescently labeled cells or the size of the tumor volume. $\mathbf{b}$ The total radiation efficiency of each group. The data are expressed as the mean $\pm \mathrm{SD}(n=10)$, and the $p$ values are shown

we showed that the growth of tumors derived from TR $\beta$ expressing SK-hep1 cells in xenograft models was inhibited in vivo. The abovementioned effects of $m-T R \beta 1$ were significantly stronger than those of TR $\beta 1$. Studies have shown that TR $\beta 1$ can inhibit the proliferation and migration of hepatocarcinoma cells and other cancer cells [2, 4, 6, 15, 23-25]. Cell apoptosis is a complicated biological process that is associated with complex signaling pathway responses. The activation of cysteine proteases, particularly caspases, is a key intracellular regulator of cell apoptosis, and Caspase-3 is an important mediator of apoptosis [26]. TR $\beta$ expression induces apoptosis in breast cancer cells via an increase in cleaved PARP and Caspase-3 levels [27-29]. One study has shown that thyroid hormone induces the expression of 4-1BB, which encodes a tumor necrosis factor (TNF) receptor superfamily protein, and the activation of caspases in a thyroid hormone receptor-dependent manner [30]. Bak is a gene that promotes tumor cell apoptosis and belongs to the $\mathrm{Bcl}$-2 gene family. Bak can promote apoptosis by inhibiting 

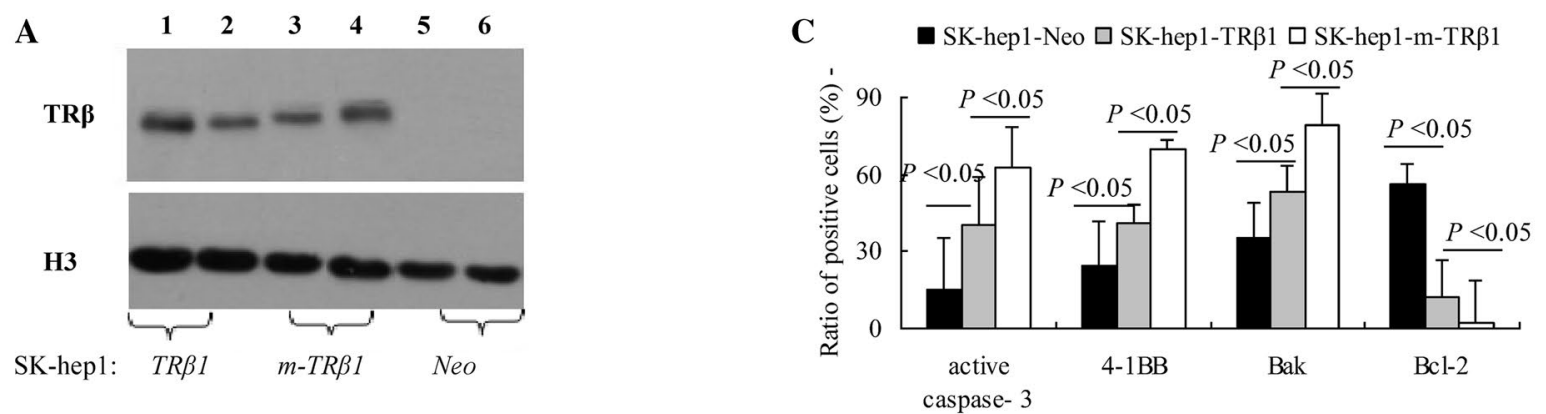

B

SK-hep1-Neo
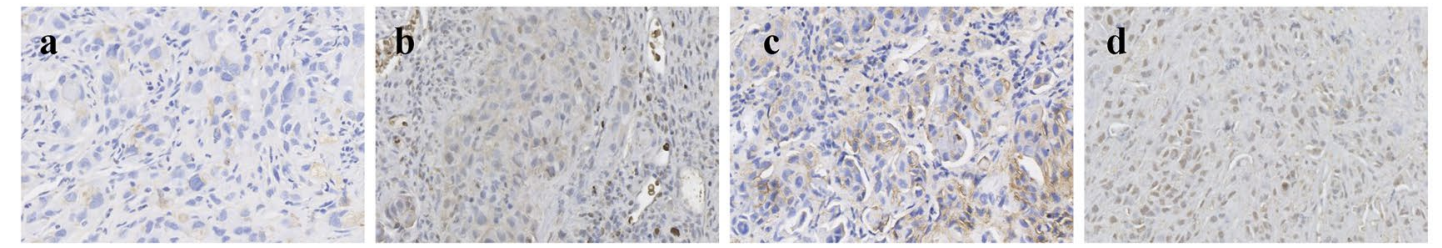

SK-hep1-TRß1

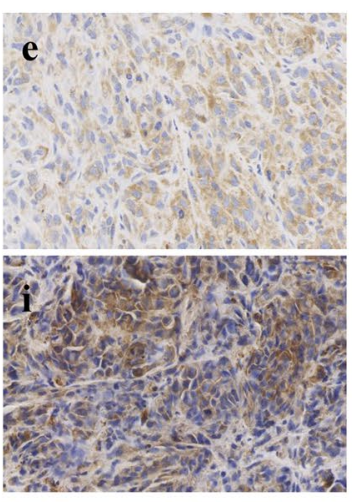

active caspase-3

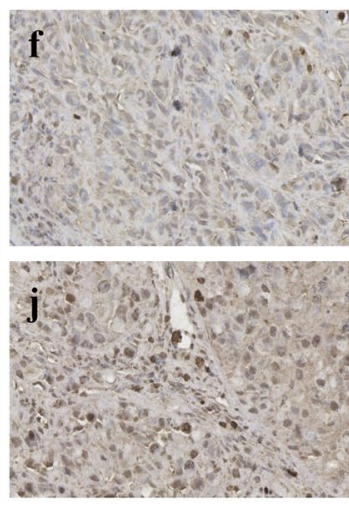

4-1BB

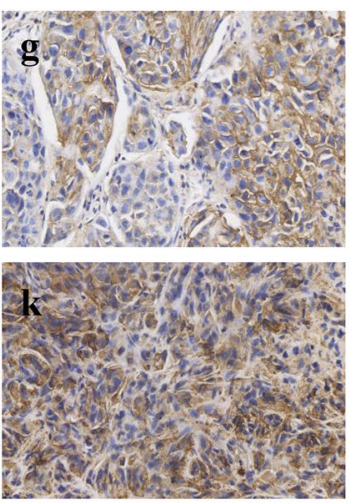

Bak

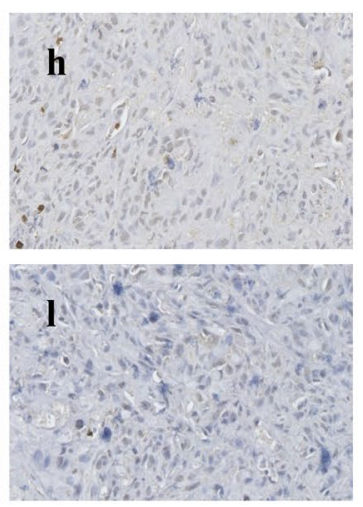

Bcl-2
Fig. 6 Western blot and immunohistochemical analysis in tumor tissues. a Western blot analysis of TR $\beta 1$ and $\mathrm{m}$-TR $\beta 1$ in tumors. Tumors were excised from the injection sites (right forelimb armpits) of nude mice, and Western blot analysis was carried as described in Materials and methods. TR $\beta 1$ (lanes 1 and 2) and m-TR $\beta 1$ (lanes 3 and 4) were expressed in the tumor tissues (SK-hep1-TR $\beta 1$ group and SK-hep1$m$-TR $\beta 1$ group) but not in the SK-hep1-Neo control group (lanes 5 and 6). b Immunohistochemical staining for active Caspase-3, 4-1BB, $\mathrm{Bcl}-2$, and Bak $(200 \times)$. Sections of the tumors derived from the Neo

the anti-apoptotic activity of Bcl-2 and Bcl-xl or by activating a pathway that is similar to that of the TNF death receptors. The involvement of pro-apoptotic Bak in the course and treatment of hepatocarcinoma has been reported [31, 32]. The level of Bak is reduced or even non-detectable in hepatocarcinoma cells, and this reduction in Bak contributes to the development and progression of hepatocarcinoma $[33,34]$. In the present study, we found that in the presence of T3, m-TR $\beta 1$ inhibited proliferation and migration and promoted the apoptosis of SK-hep1 cells by up-regulating Caspase-3, 4-1BB, and Bak expression, increasing Caspase-3 activity and down-regulating $\mathrm{Bcl}-2$ expression (see Figs. 3, 6). The present study also demonstrates that the control cells (panels a-d), SK-hep1-TR $\beta 1$ cells (panels e-h), and SK-hep1- $m$-TR $\beta 1$ cells (panels $\mathrm{i}-1$ ) were treated with anti-active Caspase-3 antibodies (panels a, e and i), anti-4-1BB antibodies (panels $\mathrm{b}, \mathrm{f}$ and $\mathrm{j}$ ), anti-Bak antibodies (panels c, $g$ and $\mathrm{k}$ ), or with anti-Bcl-2 antibodies (panels d, h, and l) as described in Materials and methods. c These positive cells were counted from three different sections and expressed as the percentage of positive cells versus the total number of cells examined. The data are expressed as the mean $\pm \operatorname{SD}(n=10)$. The $p$ values are shown

expression of m-TR $\beta 1$ impedes SK-hep1 tumor development in vivo (see Figs. 4, 5). At the same time, the abovementioned effects of $\mathrm{m}-\mathrm{TR} \beta 1$ are obviously stronger than those of TR $\beta 1$. These results suggest that modification of the DBD region may alter the TR $\beta$ activation intensity of target genes. Thus, the present study provides evidence to support the idea that m-TR $\beta 1$ can act as a tumor suppressor in human hepatocarcinoma development and progression. Other potential mechanisms that may underlie the m-TR $\beta 1$-mediated antiproliferative effect await further studies in the future.

Our study demonstrates that m-TR $\beta 1$ expression in SKhep 1 cells decreases cancer cell proliferation, impedes tumor cell migration, and inhibits tumor growth in vivo 
by up-regulating Caspase-3, 4-1BB, and Bak expression, increasing Caspase- 3 activity, and down-regulating $\mathrm{Bcl}-2$ expression. In addition, the anti-tumor effects of m-TR $\beta 1$ are significantly stronger than those of TR $\beta 1$. These findings indicate that $\mathrm{m}-\mathrm{TR} \beta$ can act as a tumor suppressor in hepatocarcinoma.

Author Contributions RZ designed the project, contributed to all experiments and to writing the manuscript. XP contributed to all experiments and to writing the manuscript. YZ was mainly responsible for the analysis of data and for writing the manuscript. YS, WS, XM, and $\mathrm{CZ}$ conducted the experiments. All authors read and provided their approval for the final version of the manuscript.

Funding This work was supported by grants from the National Natural Science Foundation of China (Nos. 81770915 and 81301737) and the Shandong Provincial Natural Science Foundation, China (Nos. ZR2012HQ034, ZR2015HL025, ZR2016BL19, and ZR2015HM028).

\section{Compliance with ethical standards}

Conflict of interest The authors declare that they have no conflicts of interest.

Ethical approval All applicable international, national, and/or institutional guidelines for the care and use of animals were followed.

Database linking GenBank: DQ191165.

Open Access This article is distributed under the terms of the Creative Commons Attribution 4.0 International License (http://creativeco mmons.org/licenses/by/4.0/), which permits unrestricted use, distribution, and reproduction in any medium, provided you give appropriate credit to the original author(s) and the source, provide a link to the Creative Commons license, and indicate if changes were made.

\section{References}

1. Cheng SY, Leonard JL, Davis PJ (2010) Molecular aspects of thyroid hormone actions. Endocr Rev 31:139-170. https://doi. org/10.1210/er.2009-0007

2. Kim WG, Zhao L, Kim DW, Willingham MC, Cheng SY (2014) Inhibition of tumorigenesis by the thyroid hormone receptor $\beta$ in xenograft models. Thyroid 24:260-269. https://doi.org/10.1089/ thy.2013.0054

3. Paquette MA, Atlas E, Wade MG, Yauk CL (2014) Thyroid hormone response element half-site organization and its effect on thyroid hormone mediated transcription. PLoS ONE 9:e101155. https://doi.org/10.1371/journal.pone.0101155

4. Zhu L, Tian G, Yang Q, De G, Zhang Z, Wang Y, Nie H, Zhang Y, Yang X, Li J (2016) Thyroid hormone receptor $\beta 1$ suppresses proliferation and migration by inhibiting PI3K/Akt signaling in human colorectal cancer cells. Oncol Rep 36:1419-1426. https:// doi.org/10.3892/or.2016.4931

5. García-Silva S, Martínez-Iglesias O, Ruiz-Llorente L, Aranda A (2011) Thyroid hormone receptor $\beta 1$ domains responsible for the antagonism with the ras oncogene: role of corepressors. Oncogene 30:854-864. https://doi.org/10.1038/onc.2010.464
6. Martínez-Iglesias O, Olmeda D, Alonso-Merino E, Gómez-Rey S, González-López AM, Luengo E, Soengas MS, Palacios J, Regadera J, Aranda A (2016) The nuclear corepressor 1 and the thyroid hormone receptor $\beta$ suppress breast tumor lymphangiogenesis. Oncotarget 7:78971-78984. https://doi.org/10.18632/oncotarget .12978

7. Kim WG, Cheng SY (2013) Thyroid hormone receptors and cancer. Biochim Biophys Acta 1830:3928-3936. https://doi. org/10.1016/j.bbagen.2012.04.002

8. Ling Y, Shi X, Wang Y, Ling X, Li Q (2014) Down-regulation of thyroid hormone receptor $\beta 1$ gene expression in gastric cancer involves promoter methylation. Biochem Biophys Res Commun 444:147-152. https://doi.org/10.1016/j.bbrc.2014.01.012

9. Rosignolo F, Maggisano V, Sponziello M, Celano M, Di Gioia CR, D’Agostino M, Giacomelli L, Verrienti A, Dima M, Pecce V, Durante C (2015) Reduced expression of THR $\beta$ in papillary thyroid carcinomas: relationship with BRAF mutation, aggressiveness and miR expression. J Endocrinol Investig 38:1283-1289. https://doi.org/10.1007/s40618-015-0309-4

10. Master A, Wójcicka A, Piekiełko-Witkowska A, Bogusławska J, Popławski P, Tański Z, Darras VM, Williams GR, Nauman A (2010) Untranslated regions of thyroid hormone receptor beta 1 mRNA are impaired in human clear cell renal cell carcinoma. Biochim Biophys Acta 1802:995-1005. https://doi.org/10.1016/j. bbadis.2010.07.025

11. Tseng YH, Huang YH, Lin TK, Wu SM, Chi HC, Tsai CY, Tsa MM, Lin YH, Chang WC, Chang YT, Chen WJ, Lin KH (2013) Thyroid hormone suppresses expression of stathmin and associated tumor growth in hepatocellular carcinoma. Sci Rep 6:38756. https://doi.org/10.1038/srep38756

12. Charalampoudis P, Agrogiannis G, Kontzoglou K, Kouraklis G, Sotiropoulos GC (2017) Thyroid hormone receptor alpha (TRa) tissue expression in ductal invasive breast cancer: a study combining quantitative immunohistochemistry with digital slide image analysis. Eur J Surg Oncol 43:1428-1432. https://doi. org/10.1016/j.ejso.2017.05.012

13. Zhu XG, Zhao L, Willingham MC, Cheng SY (2010) Thyroid hormone receptors are tumor suppressors in a mouse model of metastatic follicular thyroid carcinoma. Oncogene 29:1909-1919. https://doi.org/10.1038/onc.2009.476

14. Park JW, Zhao L, Willingham MC, Cheng SY (2017) Loss of tyrosine phosphorylation at Y406 abrogates the tumor suppressor functions of the thyroid hormone receptor $\beta$. Mol Carcinog 56:489-498. https://doi.org/10.1002/mc.22511

15. Park JW, Zhao L, Willingham M, Cheng SY (2015) Oncogenic mutations of thyroid hormone receptor $\beta$. Oncotarget 6:8115-8131

16. Ling Y, Ling X, Fan L, Wang Y, Li Q (2015) Mutation analysis underlying the downregulation of the thyroid hormone receptor $\beta 1$ gene in the Chinese breast cancer population. Onco Targets Ther 8:2967-2972. https://doi.org/10.2147/OTT.S93418

17. Liao CH, Yeh CT, Huang YH, Wu SM, Chi HC, Tsai MM, Tsai CY, Liao CJ, Tseng YH, Lin YH, Chen CY, Chung IH, Cheng WL, Chen WJ, Lin KH (2012) Dickkopf 4 positively regulated by the thyroid hormone receptor suppresses cell invasion in human hepatoma cells. Hepatology 55:910-920. https://doi.org/10.1002/ hep. 24740

18. Guigon CJ, Kim DW, Zhu X, Zhao L, Cheng SY (2010) Tumor suppressor action of liganded thyroid hormone receptor beta by direct repression of beta-catenin gene expression. Endocrinology 151:5528-5536. https://doi.org/10.1210/en.2010-0475

19. Park JW, Zhao L, Webb P, Cheng SY (2014) Src-dependent phosphorylation at Y406 on the thyroid hormone receptor $\beta$ confers the tumor suppressor activity. Oncotarget 5:10002-100016

20. Zhao RL, Sun B, Liu Y, Li JH, Xiong WL, Liang DC, Guo G, Zuo AJ, Zhang JY (2014) Cloning and identification of a novel thyroid hormone receptor $\beta$ isoform expressed in the pituitary 
gland. Mol Cell Biochem 389:141-150. https://doi.org/10.1007/ s11010-013-1935-9

21. Kim WG, Zhu X, Kim DW, Zhang L, Kebebew E, Cheng SY (2013) Reactivation of the silenced thyroid hormone receptor $\beta$ gene expression delays thyroid tumor progression. Endocrinology 154:25-35. https://doi.org/10.1210/en.2012-1728

22. Martinez-Iglesias O, Garcia-Silva S, Tenbaum SP, Regadera J, Larcher F, Paramio JM, Vennstrom B, Aranda A (2009) Thyroid hormone receptor beta1 acts as a potent suppressor of tumor invasiveness and metastasis. Cancer Res 69:501-509. https://doi. org/10.1158/0008-5472.CAN-08-2198

23. Ruiz-Llorente L, Martínez-Iglesias O, García-Silva S, Tenbaum S, Regadera J, Aranda A (2011) The thyroid hormone receptors as tumor suppressors. Horm Mol Biol Clin Investig 5:79-89. https ://doi.org/10.1515/HMBCI.2010.045

24. Wu SM, Cheng WL, Liao CJ, Chi HC, Lin YH, Tseng YH, Tsai CY, Chen CY, Lin SL, Chen WJ, Yeh YH, Huang CY, Chen MH, Yeh YC, Lin KH (2015) Negative modulation of the epigenetic regulator, UHRF1, by thyroid hormone receptors suppresses liver cancer cell growth. Int J Cancer 137:37-49. https://doi. org/10.1002/ijc. 29368

25. Chi HC, Liao CH, Huang YH, Wu SM, Tsai CY, Liao CJ, Tseng YH, Lin YH, Chen CY, Chung IH, Wu TI, Chen WJ, Lin KH (2013) Thyroid hormone receptor inhibits hepatoma cell migration through transcriptional activation of Dickkopf 4. Biochem Biophys Res Commun 439:60-65. https://doi.org/10.1016/j. bbrc.2013.08.028

26. Mu R, Lu N, Wang J, Yin Y, Ding Y, Zhang X, Gui H, Sun Q, Duan H, Zhang L, Zhang Y, Ke X, Guo Q (2010) An oxidative analogue of gambogic acid-induced apoptosis of human hepatocellular carcinoma cell line HepG2 is involved in its anticancer activity in vitro. Eur J Cancer Prev 19:61-67. https://doi. org/10.1097/CEJ.0b013e328333fb22
27. Park JW, Zhao L, Cheng SY (2013) Inhibition of estrogen-dependent tumorigenesis by the thyroid hormonereceptor $\beta$ in xenograft models. Am J Cancer Res 3:302-311

28. Shi XZ, Jin X, Xu P, Shen HM (2014) Relationship between breast cancer and levels of serum thyroid hormones and antibodies: a meta-analysis. Asian Pac J Cancer Prev 15:6643-6647

29. Gu G, Gelsomino L, Covington KR, Beyer AR, Wang J, Rechoum Y, Huffman K, Carstens R, Andò S, Fuqua SA (2015) Targeting thyroid hormone receptor beta in triple-negative breast cancer. Breast Cancer Res Treat 150:535-545. https://doi.org/10.1007/ s10549-015-3354-y

30. Yamada-Okabe T, Satoh Y, Yamada-Okabe H (2003) Thyroid hormone induces the expression of 4-1BB and activation of caspases in a thyroid hormone receptor-dependent manner. Eur J Biochem 270:3064-3073

31. Zhang Q, Ma S, Liu B, Liu J, Zhu R, Li M (2016) Chrysin induces cell apoptosis via activation of the $\mathrm{p} 53 / \mathrm{Bcl}-2 /$ caspase-9 pathway in hepatocellular carcinoma cells. Exp Ther Med 12:469-474

32. Zhang Q, Ma S, Liu B, Liu J, Zhu R, Li M (2016) DMFC (3,5-dimethyl-7H-furo[3,2-g]chromen-7-one) regulates Bim to trigger Bax and Bak activation to suppress drug-resistant human hepatoma. Apoptosis 22:381-392. https://doi.org/10.1007/s1049 5-016-1331-5

33. Rousseau B, Ménard L, Haurie V, Taras D, Blanc JF, MoreauGaudry F, Metzler P, Hugues M, Boyault S, Lemière S, Canron X, Costet P, Cole M, Balabaud C, Bioulac-Sage P, Zucman-Rossi J, Rosenbaum J (2007) Overexpression and role of the ATPase and putative DNA helicase RuvB-like 2 in human hepatocellular carcinoma. Hepatology 46:1108-1118

34. Ye CG, Chen GG, Ho RLK, Merchant JL, He ML, Lai PBS (2013) Epigenetic upregulation of Bak by ZBP-89 inhibits the growth of hepatocellularcarcinoma. Biochim Biophys Acta 1833:29702979. https://doi.org/10.1016/j.bbamcr.2013.08.001 